\title{
WHAT IS SO DIFFERENT ABOUT STEM INTERNSHIPS?
}

\author{
Kirsten E. Martinez, Western Carolina University, kemartinez1@catamount.wcu.edu \\ BarbaraJo White, Western Carolina University,whiteb@email.wcu.edu \\ Jennifer H.Williams, Western CarolinaUniversity,jhwilliams@email.wcu.edu
}

\begin{abstract}
The benefits of internships are well documented for college students and can help students choose a major, stay in their programs, network to get a job and help them in their first jobs. However, results are mixed with respect to internship characteristics such as compensation and student and supervisor characteristics such as gender and their effects on evaluations. Furthermore, little is known about how internships in STEM and non-STEM fields differ with respect to student internship evaluations and supervisor evaluations of their interns. For this study, nearly 150 student and supervisor evaluations were analyzed. Results showed that compensation and gender did not have an effect on internship evaluations and that students in STEM internships believed their supervisors gave more clear instructions, that their supervisors' had more of an open door policy in place and students were more confident in their abilities at the end of the internship experience compared to students in non-STEM internships. Implications and future research are discussed.
\end{abstract}

Keywords: Internships, STEM, Gender, Evaluations

\section{INTRODUCTION}

Very professional environment and the employees are very helpful and courteous. Most have known plus worked with each other for years and seem to be a close knit group of people. I didn't feel like an intern nor was I treated as one. I was treated as an employee and respected for my work. I would be lucky to work for an organization like [this].

"Great pay and challenging work, supervisors allow you to work at your normal pace, you contribute to actual projects."

Student Interns in STEM Internships

"Although my internship was not well structured at first, it got better with the more time I spent shadowing. After that, I was placed with someone that assigned me essential duties. I learned a lot about pro-writing as well as things like office politics."

"Overall I really did enjoy my experience here, and because it wasn't super busy with customers during the summer I did not get to experience as much as I wanted to. I just wish that tasks would have been laid out more clearly so that they could be completed to the employer's satisfaction.

Student Interns in Non-STEM Internships

The benefits of internships are well documented for both graduate [15] and undergraduate students [3, 8, 13]. For example, student internships have been shown to have a positive effect on overall student satisfaction with their international education experiences [13]. Additionally, internships function to provide students with access to career opportunities and increased access to career decision data [7]. Relating to career opportunities, student internships enhance student resumes by honing networking and technical skills as well as giving students the opportunity to interact with professionals in their fields, especially their supervisors [2]. Beyond graduation, participation in internships during their college years also provides benefits. In fact, new employees with previous internship experience had significant early career advantages including reduced time to first job acquisition, greater compensation, and increased job satisfaction [8]. With internships so critical to students who are making decisions about their college majors, deciding whether or not to remain in particular majors, like STEM majors, or entering new jobs, it is imperative that we know more about internships including how students and their supervisors evaluate the internship experiences. 


\section{INTERNSHIPS CHARACTERISTICS}

Students across many disciplines participate in internships with varying levels of satisfaction While much is known about internships and recruitment [12,16] and the positive effects students' internship job attitudes [7], for example, much less is known about how other characteristics affect supervisor and student evaluations of the student intern experience. In particular, the relationship between internship characteristics such as compensation, student gender, supervisor gender, student-supervisor gender combination, and internship field does not present clear findings.

The research on the relationship between level of satisfaction and compensation is mixed with several studies showing no relationship between compensation and internship satisfaction [3,9]. Meanwhile, other research shows that having a paid internship had a positive effect on internship evaluations [2].

The relationship between internship evaluations and gender can be studied in three different ways as researchers seek to understand how student gender, supervisor gender and the student-supervisor gender combination affect student and supervisor evaluations of internships. Regarding student gender, research has shown that in some cases student gender has not had an effect on internship assessment [1] while in other cases an effect has been recorded [14]. For example when young employees in their late 20 s were asked to rate their previous internship experiences, no difference was found between males and females while the same cannot be said for employees in their mid-30s. For that group, older females were significantly more satisfied with their previous internships compared to older males [14]. With respect to supervisor gender and evaluations of students in their internships, again, research is mixed with no differences found in some studies [1] and significant differences found in other studies [5]. For example, supervisors valued their interns who accepted challenging tasks and female interns were significantly less likely to seek or accept challenging tasks compared to male interns; thus resulting in gender-based differences [5]. Research on the relationship between internship satisfaction and the supervisor-student gender combination is also mixed in terms of supervisor and student evaluations. While supervisor internship evaluations were higher when the supervisor and student were of the same gender, gender was not a factor in students' views of work characteristics related to their internships [17].

There has been a great deal of research in the area of Science, Technology, Engineering and Math (STEM) internships but typically, it involves how to recruit students to STEM disciplines. Recent national news articles [6, 11] highlight the need for diversity in computer and tech firms from Microsoft to Google and beyond the Silicon Valley even though colleges and universities have long been interested in recruiting students to Computer Information Systems and Computer Science fields. Internship research typically investigates internships as a way of recruiting women [12], Latinos [16] and other minorities [12] to STEM disciplines. Besides recruiting students to STEM disciplines, internships are also a way to retain STEM students [12]. Not all the internships STEM students participate in are even "real"-recently, undergraduate engineering students participated in "virtual" internships with a fictitious company in order to become acculturated to the typical engineering workplace [4]. There is very little research examining differences between STEM and non-STEM internships as evaluated by students and supervisors.

This study will explore the characteristics of gender, compensation and internship field (whether the internship is in a STEM business or not) and the effects of those characteristics on internship evaluations from both supervisors and students.

\section{RESEARCH METHODOLOGY}

Internships for this study were facilitated through the on-campus office which facilitates approximately $20 \%$ of all internships with the other $80 \%$ internships facilitated by individual departments. Generally internships facilitated by the on-campus office involve information from supervisors and students. For example supervisors provide contact information along with an internship job description, mid-term evaluation, and a final evaluation. On the other hand, students fill out an internship job application, wavier, and an internship evaluation. In terms of internship evaluations, the final evaluations from supervisors and students were mandatory, while the supervisor mid-term internship evaluation was optional. Only the mandatory evaluations were included in this study. 
The student internship evaluation contained 17 items that can be loosely subdivided into career oriented items (such as "I feel that I learned a great deal in my career or professional area"), items related to soft skills (such as "My greatest learning occurred in the personal/social area"), academically-related items (such as "My academic preparation for this assignment was very adequate"), items related to interactions with supervisors (such as "My supervisor (or training instructor) gave clear, explicit instructions and did so as often as I needed them"), and overall internship experience items (such as "During this Co-op/internship term I felt I was productive for the organization"). Students rated each statement about their internship using a 4-point Likert scale with "1" = "Strongly Agree" to "4" = "Strongly Disagree" (See Appendix A).

The supervisor internship final evaluation was divided into the two categories: 10 performance record items, such as the volume and quality of work produced, and accuracy, and nine items dealing with work habits, such as initiative, organization and attitude. Supervisors rated each statement about the performance habits of their internship student using a 5-point Likert scale with " 1 " = "Outstanding" to "5" = "Unsatisfactory" (See Appendix B). Supervisors also rated each statement about the work habits of their internship student using a 3-point Likert scale with "1" = "Above Average" to "3" = "Below Average" (See Appendix B).

To better understand how internship evaluations completed by students about their experiences and how evaluations completed by supervisors about their student interns differed based on compensation, gender and the type of internship, final internship evaluations from both students and supervisors were analyzed were analyzed. Demographics for student and supervisor evaluations appear below: (see Table 1).

Table 1. Demographics

\begin{tabular}{|r|c|}
\hline \multicolumn{1}{|c|}{ Characteristic } & Number in Sample \\
\hline Supervisor Gender & 143 \\
\hline Female & 72 \\
Male & 71 \\
\hline & \\
\hline Female & 149 \\
\hline Male & 68 \\
\hline Student Intern Gender & \\
\hline Supervisor-Student Gender Combination & 143 \\
\hline Mixed Gender & 44 \\
\hline Male Supervisor-Female Intern & 25 \\
\hline Female Supervisor-Male Intern & 19 \\
\hline Same Gender & 99 \\
\hline Male Supervisor-Male Intern & 46 \\
\hline Female Supervisor-Female Intern & 53 \\
\hline Internship Compensation & \\
\hline Paid Internships & 56 \\
\hline Unpaid Internships & 89 \\
\hline Compensation Unknown & 4 \\
\hline Student Internship Field & \\
\hline STEM & 46 \\
\hline Non-STEM & 103 \\
\hline & \\
\hline & \\
\hline & \\
\hline & \\
\hline & \\
\hline & \\
\hline & \\
\hline & \\
\hline & \\
\hline & \\
\hline & \\
\hline & \\
\hline
\end{tabular}




\section{RESULTS}

Of the 158 student internship evaluations, 9 were incomplete evaluations, chiefly without ratings on all the 17 evaluation items were removed, leaving 149 that were analyzed. Of the 143 supervisor internship evaluations turned in, none were missing all the evaluation scores for items in the performance and work habit areas, so 143 were analyzed. All tests were conducted with a significance level, or alpha, of .05 that the $p$ value was measured against. An overview of results appears below (see Table 2).

Table 2. Overview of Analysis and Results

\begin{tabular}{|c|c|c|}
\hline $\begin{array}{l}\text { One-sample t- } \\
\text { test }\end{array}$ & $\begin{array}{l}\text { Used to determine whether students felt } \\
\text { significantly positive or negative about the } \\
\text { internship as measured by the } 17 \text {-item student } \\
\text { survey }\end{array}$ & $\begin{array}{l}\text { Significant difference for all items and all } \\
\text { were in a positive direction }\end{array}$ \\
\hline $\begin{array}{l}\text { One-sample t- } \\
\text { test }\end{array}$ & $\begin{array}{l}\text { Used to determine whether supervisors felt } \\
\text { significantly positive or negative about their } \\
\text { student interns as measured by the 12-item } \\
\text { student performance survey and 9-item student } \\
\text { work habits survey }\end{array}$ & $\begin{array}{l}\text { Significant difference for all items and all } \\
\text { were in a positive direction }\end{array}$ \\
\hline $\begin{array}{l}\text { Compensation: } \\
\text { Independent- } \\
\text { samples t-test }\end{array}$ & $\begin{array}{l}\text { Used to determine whether students evaluations } \\
\text { on } 17 \text { items and whether supervisor evaluations } \\
\text { on } 21 \text { items differed based on whether the } \\
\text { internship was paid or not }\end{array}$ & $\begin{array}{l}\text { No significant differences in evaluations on } \\
\text { any items between paid and unpaid } \\
\text { internships }\end{array}$ \\
\hline $\begin{array}{l}\text { Gender and } \\
\text { Student } \\
\text { Evaluations: } \\
\text { Independent- } \\
\text { samples t-test }\end{array}$ & $\begin{array}{l}\text { Used to determine whether students evaluations } \\
\text { on } 17 \text { items differed based on the gender of the } \\
\text { student }\end{array}$ & $\begin{array}{l}\text { No significant differences in evaluations on } \\
\text { any items between female and male students }\end{array}$ \\
\hline $\begin{array}{l}\text { Gender and } \\
\text { Supervisor } \\
\text { Evaluations: } \\
\text { Independent- } \\
\text { samples t-test }\end{array}$ & $\begin{array}{l}\text { Used to determine whether supervisor } \\
\text { evaluations on } 12 \text {-item student performance } \\
\text { survey and 9-item student work habits survey } \\
\text { differed based on the following three gender- } \\
\text { related conditions: the gender of the student } \\
\text { evaluated; the gender of the supervisor, and } \\
\text { whether the supervisor-student combination } \\
\text { was of the same gender or mixed gender }\end{array}$ & $\begin{array}{l}\text { No significant differences in evaluations on } \\
\text { any items between female and male students } \\
\text { evaluated; between female and male } \\
\text { supervisor evaluators; and for evaluations for } \\
\text { students and supervisors of the same gender } \\
\text { compared to differing genders }\end{array}$ \\
\hline $\begin{array}{l}\text { Internship } \\
\text { Type (STEM } \\
\text { vs. Non- } \\
\text { STEM) and } \\
\text { Student } \\
\text { Evaluations: } \\
\text { Independent- } \\
\text { samples t-test }\end{array}$ & $\begin{array}{l}\text { Used to determine whether students evaluations } \\
\text { on } 17 \text { items differed based on whether the } \\
\text { student was in a STEM internship or a non- } \\
\text { STEM internship }\end{array}$ & $\begin{array}{l}\text { No significant differences in evaluations for } \\
\text { students in STEM compared to non- } \\
\text { STEM internships on } 13 \text { of the } 17 \text { items. } \\
\text { Significant differences existed for the other } \\
\text { four items. Compared to non-STEM student } \\
\text { interns, STEM students were more confident } \\
\text { in their abilities following their internship; } \\
\text { STEM students thought their supervisors } \\
\text { gave clearer instructions; and had more of an } \\
\text { open-door policy; and lastly, STEM student } \\
\text { would recommend their employer more } \\
\text { highly. }\end{array}$ \\
\hline
\end{tabular}

\section{Student Internship Evaluations}

A one-sample t-test was performed to determine whether the 17 student internship evaluation items differed significantly from the neutral mid-point item, 2.5. Means were all statistically significantly higher than the neutral mid-point for all items. All were in a more positive direction including: challenging, $t(148)=-12.020, p<.000$; performance, $t(143)=-12.49, p<.000$; clear instructions, $t(148)=-15.67, p<.000$; open door, $t(147)=-25.60, p<$ 
.000 ; meaningful, $t(148)=-16.666, p<.000$; productive, $t(145)=-16.942, p<.000$; oral communication, $t(141)=$ 20.76, $p<.000$; written communication, $t(135)=-21.82, p<.000$; training, $t(141)=-6.63, p<.000$; career learning; $t(147)=-15.79, p<.000$, social learning, $t(141)=-8.58, p<.000$; compensation, $t(79)=-10.12, p<.000$; degree motivation, $t(136)=-19.08, p<.000$; confirm career, $t(144)=-13.78, p<.000$; future courses, $t(96)=-3.51, p<$ .000 ; competitive, $t(147)=-20.10, p<.000$; confident, $t(146)=-19.48, p<.000$; adequate academic preparation, $t(142)=-13.41, p<.000$; and recommendation for employer, $t(146)=-15.37, p<.000$.

\section{Supervisor Internship Evaluation}

A one-sample t-test was performed to determine whether the 10 performance record evaluation items differed significantly from the neutral mid-point item, 3 and whether the nine work habit evaluation items differed significantly from the neutral mid-point item, 2 .

Means for the performance record items were all statistically significantly higher than the neutral mid-point for all performance record items including: volume of work produced, $t(142)=-21.809, p<.000$; quality of the work produced, $t(142)=-22.59, p<.000$; analytical ability, $t(139)=-21.08, p<.000$; ability to solve problems, $t(141)=-$ $19.90, p<.000$; accuracy and thoroughness, $t(141)=-20.07, p<.000$; ability to work under pressure, $t(137)=-$ $16.94, p<.000$; oral communication, $t(141)=-20.76, p<.000$; written communication, $t(135)=-22.54, p<.000$; original and creative thinking, $t(141)=-21.54, p<.000$; and ability to learn; $t(142)=-29.55, p<.000$.

Means for the work habit evaluation items were all statistically significantly higher than the neutral mid-point for all work habit evaluation items including: preparing and organizing work, $t(142)=-21.35, p<.000$; initiative, $t(141)=$ $-18.12, p<.000$; ability to adjust to non-routine assignments, $t(140)=-23.77, p<.000$; keeps constructively busy, $t(142)=-25.28, p<.000$; healthy attitude toward company policies and objectives, $t(141)=-25.10, p<.000$; cooperative in working relationships, $t(141)=-29.36, p<.000$; exhibits diligence and perseverance, $t(141)=-24.53$, $p<.000$; performs tasks with industry and drive, $t(142)=-22.21, p<.000$; and demonstrates a willingness to accept responsibility, $t(142)=-28.72, p<.000$.

\section{Internship Evaluations and Compensation}

An independent samples t-test was used to determine whether supervisor and student evaluations differed based on whether the student worked in a paid or unpaid internship. Student internship evaluations did not differ based on whether the internship was a paid internship or whether it was an unpaid internship. Similarly, supervisor internship evaluations for student performance record items and student work habit items for paid internships were not statistically significantly different from supervisor evaluations for performance record items and student work habit items for unpaid internships.

\section{Internship Evaluations and Gender}

An independent samples t-test was used to determine whether student evaluations differed based on student gender. Results showed that student internship evaluations for the items measured did not differ based on their gender. An independent samples t-test was used to determine whether supervisor evaluations of students differed based on student gender, supervisor gender and the combination of student-supervisor gender with students and supervisors of the same or of different genders. Results showed that supervisor internship evaluations for student performance record items and student work habit items for paid internships were not statistically significantly different based on whether the student intern had a male or female supervisor. In addition, results showed that supervisor internship evaluations for performance record items and student work habit items for male student interns were not statistically significantly different from evaluations for female student interns. Furthermore, results showed that supervisor evaluations for performance record items and student work habit items did not differ when students and supervisors were of the same gender compared to situations in which students and their supervisors were of different genders.

\section{Internship Evaluations for Differing Internship Fields}

For the other items on the student evaluation, results showed that with respect to whether the internship was in a STEM field compared to a non-STEM field there were no differences between the ways that students in STEM and 
non-STEM internships rated their experiences using the majority of items in the 17 item scale located in Appendix A. However, STEM students rated their internship experiences more highly compared to non-stem students on four items. With respect to the clarity of instructions from their supervisors, Students in STEM internships believed their supervisors gave clearer instructions $(M=1.30, S D=0.51)$ than students in non-STEM internships $(M=1.59, S D=$ 0.86 ), $t(135)=-2.55, p=.012$ (two-tailed). Furthermore, students in STEM internships believed their supervisors had more of an open-door policy $(M=1.15, S D=0.36)$ than students in non-STEM internships $(M=1.33, S D=$ $0.65), t(139)=-2.16, p=.032$ (two-tailed). In terms of confidence, students in STEM internships felt more confident afterwards $(M=1.27, S D=0.50)$ than students in non-STEM internships $(M=1.51, S D=0.71), t(141)=-2.38, p=$ .019 (two-tailed) and would more highly recommend their employer $(M=1.30, S D=0.63)$ than students in nonSTEM internships $(M=1.57, S D=0.85), t(116)=-2.615, p=.034)$ (two-tailed).

\section{CONCLUSIONS}

Overall, students highly rated their internships and their supervisors gave high ratings for their work. For all items on the supervisor evaluations, supervisors gave students significantly high evaluations. In terms of the ways supervisors evaluated their student interns, it was not surprising that there were no significant differences between evaluations based on student compensation, student gender, supervisor gender and the gender mix of the supervisor and student. Similarly, for all items on the internship evaluation that students completed, students also gave their internships significantly high evaluations and as with supervisors, there were no significant differences between evaluations based on student compensation, student gender, supervisor gender and the gender mix of the supervisor and student.

Generally, STEM and non-STEM students did not differ on their evaluations for a majority of items on evaluation form. However, student evaluations did differ for four items based on whether the student was in a STEM internship or not, with STEM students feeling more confident in their abilities at the end of their internship and recommending their employer more highly, and believing their supervisors gave more clear directions and had a more open door policy compared to non-STEM students. Given that many professors have noticed their millennial students need more direction compared to previous generations, the notion that millennial students in internships value and need direction from supervisors is not surprising and may be an indication of generational differences in the workplace [10]. However, the idea that student interns in STEM internships thought their supervisors gave clearer directions and had a more open door policy may be attributed to the notion that STEM jobs are more structured, which in turn may require more communication or that supervisors spend more time or communicate more with employees in certain positions. With the critical need for STEM graduates, particularly minorities [6,11], making national news headlines, supervisors may perceive their STEM interns as very important and may therefore spend more time communicating with them. Given that STEM interns rated themselves as more confident in their abilities as a result of the internship compared to non-STEM interns and given that supervisors tend to value confident employees and their work contributions [18], this may explain why supervisors communicated more with STEM interns than nonSTEM interns.

Based on student evaluations of internships, using items in Appendix A and supervisor evaluations, using items in Appendix B, our results show that it doesn't matter if a student is male or female, if the student's supervisor is male or female or of the same gender as the student or not, or if the internship is paid or not - in all cases, students highly rate their internships and are highly rated by their supervisors. It's wise for university personnel to continue encouraging students to search for and experience internship work. Given that students in STEM internships felt more confident about their abilities, would recommend their employer more highly and felt their supervisor provided more clear explanations and had more of an open-door policy, it may be wise for the same university personnel to provide information to employers about the students' potential needs for interaction with their supervisors and to provide students with a realistic preview of differences in levels of interaction they had with professors from levels of interaction they are likely to have with their supervisors in the workplace. Further research is needed in order to understand the differences between student and supervisor evaluations in STEM and nonSTEM internships. 


\section{REFERENCES}

1. Alpert, F., Heaney, J. G., \& Kuhn, K. A. L. (2009). Internships in marketing: Goals, structures and assessmentStudent, company and academic perspectives. Australasian Marketing Journal (AMJ), 17(1), 36-45.

2. Beebe, A., Blaylock, A., \& Sweetser, K. D. (2009). Job satisfaction in public relations internships. Public Relations Review, 35 (2), 156-158.

3. D'Abate, C. P., Youndt, M. A., \& Wenzel, K. E. (2009). Making the most of an internship: An empirical study of internship satisfaction. Academy of Management Learning \& Education, 8(4), 527-539.

4. D’Angelo, C., Arastoopour, G., Chesler, N., \& Shaffer, D. W. (2011). Collaborating in a virtual engineering internship. In Computer Supported Collaborative Learning Conference.

5. De Pater, I. E., Van Vianen, A. E., Fischer, A. H., \& Van Ginkel, W. P. (2009). Challenging experiences: Gender differences in task choice. Journal of Managerial Psychology, 24(1), 4-28.

6. Emerson, J (2015, February 25). "Diversity: Tech companies need new strategies." Available: http://www.usatoday.com/story/tech/columnist/2015/02/25/joelle-emerson-column-technology-diversity-socialscience-research/24002013/

7. Feldman, D. C., \& Weitz, B. A. (1990). Summer interns: Factors contributing to positive developmental experiences. Journal of Vocational Behavior, 37(3), 267-284.

8. Gault, J., Redington, J., \& Schlager, T. (2000). Undergraduate business internships and career success: Are they related? Journal of marketing education, 22(1), 45-53.

9. Gupta, P., Burns, D. J., \& Schiferl, J. S. (2010). An exploration of student satisfaction with internship experiences in marketing. Business Education \& Administration, 2(1), 27-37.

10. Gursoy, D., Chi, C. G. Q., \& Karadag, E. (2013). Generational differences in work values and attitudes among frontline and service contact employees. International Journal of Hospitality Management, 32, 40-48.

11. Guynn, J. (2015, May 6). "Exclusive: Google raising stakes on diversity". Available: http://www.usatoday.com/story/tech/2015/05/05/google-raises-stakes-diversity-spending/26868359/

12. Kendricks, K. D., Nedunuri, K. V., \& Arment, A. R. (2013). Minority student perceptions of the impact of mentoring to enhance academic performance in STEM disciplines. Journal of STEM Education: Innovations and Research, 14(2), 38.

13. Matthews, J., \& Lawley, M. (2011). Student satisfaction, teacher internships, and the case for a critical approach to international education. Discourse: studies in the cultural politics of education, 32(5), 687-698.

14. Moyes, G. D., Williams, P. A., \& Koch, B. (2006). The effects of age and gender upon the perceptions of accounting professionals concerning their job satisfaction and work-related attributes. Managerial Auditing Journal, 21(5), 536-561.

15. Petrila, A., Fireman, O., Fitzpatrick, L. S., Hodas, R. W., \& Taussig, H. N. (2015). Student satisfaction with an innovative internship. Journal of Social Work Education, 51(1), 121-135.

16. Santiago, D., \& Soliz, M. (2012). Finding Your Workforce: The Top 25 Institutions Graduating Latinos in Science, Technology, Engineering, and Math (STEM) by Academic Level--2009-10. Third in a Series Linking College Completion with US Workforce Needs. Excelencia in Education (NJ1).

17. Smayling, M., \& Miller, H. (2012). Job satisfaction and job performance at the internship level. Journal of Leadership, Accountability and Ethics, 9(1), 27-33.

18. Tannen, D. (1995). The power of talk: Who gets heard and why. Harvard Business Review, 73(5), 138-148. 


\section{APPENDIX A}

Student Internship Evaluation Survey Items

\section{Student Evaluation Survey Items}

1. My academic preparation for this assignment was very adequate.

2. My Co-op/internship helped me to determine some of the courses I wanted to take when I returned to campus.

3. My Co-op/internship increased my motivation to obtain a four-year degree.

4. My Co-op/internship experience was challenging. I was constantly given tasks that were new and/or varied.

5. Performance of my job duties was essential to the employer. If I had not been there, someone else would have had to perform the functions of my job.

6. During this Co-op/internship term I felt that I was productive for the organization.

7. My training assignment was very well structured. The employer had a training plan in mind for the Co-op/internship.

8. Financial compensation for the work I performed was adequate.

9. I am more confident of my abilities as a result of my Co-op/internship.

10. My greatest learning occurred in the personal/social area.

11. My Co-op/internship confirmed my career plans.

12. I believed my Co-op/internship will make me more competitive in the job market when I graduate.

13. I feel that I learned a great deal in my career or professional area.

14. My supervisor has an open-door policy. I could contact him/her whenever I needed to talk with him/her.

15. My supervisor (or training instructor) gave clear, explicit instructions and did so as often as I needed them.

16. I felt that my employer did everything possible to make my experience significant and meaningful.

17. I recommend this employer for prospective Co-op/interns. If you do not recommend your employer, please give company and work site below in comments.

\begin{tabular}{|c|c|c|c|}
\hline \multicolumn{2}{|c|}{$\begin{array}{c}1= \\
\text { Strongly } \\
\text { Agree }\end{array}$} & - & $\begin{array}{c}4= \\
\text { Strongly } \\
\text { Disagree }\end{array}$ \\
\hline 1 & 2 & 3 & 4 \\
\hline 1 & 2 & 3 & 4 \\
\hline
\end{tabular}

$\begin{array}{llll}1 & 2 & 3 & 4\end{array}$

$\begin{array}{llll}1 & 2 & 3 & 4\end{array}$

$\begin{array}{llll}1 & 2 & 3 & 4\end{array}$

$\begin{array}{llll}1 & 2 & 3 & 4\end{array}$

$\begin{array}{llll}1 & 2 & 3 & 4\end{array}$

$\begin{array}{llll}1 & 2 & 3 & 4\end{array}$

$\begin{array}{llll}1 & 2 & 3 & 4\end{array}$

$\begin{array}{llll}1 & 2 & 3 & 4\end{array}$

$\begin{array}{llll}1 & 2 & 3 & 4\end{array}$

$\begin{array}{llll}1 & 2 & 3 & 4\end{array}$

$\begin{array}{llll}1 & 2 & 3 & 4\end{array}$

$\begin{array}{llll}1 & 2 & 3 & 4\end{array}$

$\begin{array}{llll}1 & 2 & 3 & 4\end{array}$

$\begin{array}{llll}1 & 2 & 3 & 4\end{array}$


APPENDIX B: Supervisor Internship Evaluation Survey Items

\section{Supervisor Evaluation of Student Performance Record}

1. Volume of work produced

2. Quality of work produced

3. Analytic ability

4. Sensitivity to problems, ability to solve them

5. Accuracy and thoroughness

6. Ability to work under pressure

7. Effectiveness in oral communication

8. Effectiveness in written communication

9. Original and creative thinking

10. Ability to learn

11. Other (please specify)

12. Overall performance

\section{Supervisor Evaluation of Student Work Habits}

1. Effective in preparing and organizing work.

2. Takes the initiative, a self-starter.

3. Has ability to adjust to non-routine assignments.

4. Keeps constructively busy and mentally alert.

5. Has healthy attitude towards company objectives/policies.

6. Is cooperative in working relationships with others.

7. Exhibits diligence and perseverance.

8. Performs tasks with industry and drive.

9. Demonstrates a willingness to accept responsibilities.

\begin{tabular}{llllr}
$\begin{array}{l}\text { Strongly } \\
\text { Agree }\end{array}$ & & - & \multicolumn{2}{c}{$\begin{array}{c}5= \\
\text { Strongly } \\
\text { Agree }\end{array}$} \\
1 & 2 & 3 & 4 & 5 \\
1 & 2 & 3 & 4 & 5 \\
1 & 2 & 3 & 4 & 5 \\
1 & 2 & 3 & 4 & 5 \\
1 & 2 & 3 & 4 & 5 \\
1 & 2 & 3 & 4 & 5 \\
1 & 2 & 3 & 4 & 5 \\
1 & 2 & 3 & 4 & 5 \\
1 & 2 & 3 & 4 & 5 \\
1 & 2 & 3 & 4 & 5 \\
1 & 2 & 3 & 4 & 5 \\
1 & 2 & 3 & 4 & 5
\end{tabular}

$\begin{array}{ccc}\begin{array}{c}\text { 1= } \\ \text { Above Average }\end{array} & \begin{array}{c}\mathbf{2}= \\ \text { Average }\end{array} & \begin{array}{c}\mathbf{3}= \\ \text { Below } \\ \text { Average }\end{array} \\ 1 & 2 & 3 \\ 1 & 2 & 3 \\ 1 & 2 & 3 \\ 1 & 2 & 3 \\ 1 & 2 & 3 \\ 1 & 2 & 3 \\ 1 & 2 & 3 \\ 1 & 2 & 3 \\ 1 & 2 & 3\end{array}$

